\title{
KINERJA KEUANGAN DAERAH YANG DIMODERASI BELANJA MODAL TERHADAP PERTUMBUHAN EKONOMI
}

\author{
Linawati \\ Mar'atus Solikah \\ Fakutas Ekonomi, Universitas Nusantara PGRI Kediri \\ Email: linawati@unpkediri.ac.id \\ Email: solikah@unpkediri.ac.id
}

\begin{abstract}
Abstrak
Kinerja keuangan yang terencana, dengan estimasi dan realisasi pendapatan dan ketepatan pengalokasian belanja, diharapkan dapat meningkatkan pertumbuhan ekonomi. Pertumbuhan ekonomi yang meningkat menandakan bahwa kegiatan perekonomian suatu daerah meningkat yang diikuti dengan meningkatnya pendapatan dan kesejahteraan masyarakatnya. Adapun kinerja keuangan diduga tidak selalu meningkatkan pertumbuhan ekonomi. Tujuan penelitian ini untuk menganalisis pengaruh kinerja keuangan daerah terhadap pertumbuhan ekonomi yang dimoderasi belanja modal pada Kota dan Kabupaten di wilayah Karesidenan Kediri. Populasi dalam penelitian ini kota dan kabupaten di wilayah Karesidenan Kediri. Obyek penelitian adalah kinerja keuangan daerah, belanja modal, dan pertumbuhan ekonomi. Data yang digunakan adalah data sekunder, terdiri atas data anggaran realisasi APBD dan pertumbuhan ekonomi, yang didapat dari website BPS dan DPJK. Analisis data menggunakan analisis Moderating. Penelitian ini mendapatkan hasil bahwa kinerja keuangan tidak berpengaruh siginikan dan bernilai negatif terhadap pertumbuhan ekonomi. Belanja modal berpengaruh negatif signifikan terhadap pertumbuhan ekonomi, dan belanja modal dapat sebagai moderator kinerja keuangan daerah terhadap pertumbuhan ekonomi.
\end{abstract}

Kata kunci: pertumbuhan ekonomi, belanja modal, kinerja keuangan daerah.

\begin{abstract}
Planned financial performance, with estimates and realization of revenues and accuracy of expenditure allocation, is expected to increase economic growth. Increased economic growth indicates increased the economic activities of that area, followed by increasing income and the welfare of its people. The financial performance is allegedly not always increasing economic growth. The purpose of this study was to analyze the effect of regional financial performance on economic growth which moderated capital expenditure in the City and Regency of the Kediri Residency. The population in this study are regionsin the Kediri. The object of research is regional financial performance, capital expenditure and economic growth. The data used is secondary data, consisting of budget data on APBD realization and economic growth, obtained from the bps and dpjk websites. Data analysis using SEM Moderating analysis. This study has found that financial performance does not have a significant and negative effect on economic growth. Capital expenditure has a significant negative effect on economic growth, and capital expenditure can be as a moderator of regional financial performance towards economic growth.
\end{abstract}

Keywords: economic growth, capital expenditure, regional financial performance. 


\section{PENDAHULUAN}

Pertumbuhan ekonomi merupakan indikator keberhasilan pembangunan suatu daerah. Dengan adanya pertumbuhan ekonomi yang semakin meningkat dari tahun ke tahun, memberikan gambaran adanya aktivitas perekonomian daerah dapat menghasilkan peningkatan pendapatan masyarakat daerah tersebut dalam kurun waktu tertentu. Dengan tercapainya pertumbuhan ekonomi yang tinggi, memberikan arti secara tidak langsung kesejahteraan masyarakat juga meningkat. Peningkatan pertumbuhan ekonomi daerah dari tahun ke tahun dapat dipengaruhi dengan desentralisasi fiskal yang tercermin dalam pelaksanaan otonomi daerah. Desentralisasi fiskal merupakan pelimpahan wewenang dalam pengambilan keputusan dari pemerintah tingkat tinggi kepada pemerintah di tingkat rendah. Pelimpahan wewenang berperan dalam meningkatkan efisiensi publik dalam jangka waktu panjang (Ani dan Dwirandra, 2014). Dengan adanya pemerintahan yang terdesentralisasi, maka suatu pemerintah daerah dituntut untuk meningkatkan kinerjanya dalam memberikan pelayanan kepada publik atau masyarakat luas di daerahnya. Pelayanan dapat berbentuk fisik maupun non fisik. Pelayanan dalam bentuk fisik dapat berupa tersedianya infrastruktur yang memadai. Infrakstrukur dapat berupa jalan, jembatan, pasar, yang dipergunakan untuk akses percepatan kegiatan perekonomian, yang dapat meningkatkan pertumbuhan ekonomi. Infrastruktur yang disediakan oleh pemerintah dipergunakan sebagai fasilitas dalam mencapai pertumbuhan ekonomi, karena dapat meningkatkan sumber daya dan produktivitas ekonomi.

Pertumbuhan ekonomi yang tinggi tidak terlepas dari kinerja daeerah dalam melakukan pengelolaan atas keuangan daerah. Keuangan daerah harus dikelola dengan tertib, patuh pada peraturan perundang-undangan, transparan, efisien, efektif, ekonomis, dan bertanggung jawab dengan memperhatikan azas keadilan, kepatuhan, serta bermanfaat bagi masyarakat (Pasal 4 ayat 1, Permendagri No. 13, 2006). Penilaian terhadap kinerja pemerintah daerah dapat diukur dari analisis terhadap Anggaran Pendapatan dan Belanja Daerah (APBD) baik target maupun realisasinya. Hasil analisis terhadap APBD dapat dipergunakan sebagai dasar informasi dalam membuat kebijakan pengelolaan keuangan daerah dan keberhasilan daerah dalam mengelola keuangannya. Kinerja keuangan daerah dapat diukur dari membandingkan tingkat target dan realisasi dari Pendapatan Asli Daerah (PAD), tingkat PAD dengan semua 
pendapatan daerah, efektivitas dari pendapatan dan belanja, efisiensi pendapatan dan belanja dan masih banyak lainnya.

Kinerja keuangan daerah dapat berdampak pada pertumbuhan ekonomi. Semakin meningkat penerimaan PAD dalam suatu daerah memberikan gambaran meningkatnya pertumbuhan ekonomi daerah tersebut. Dengan meningkatnya PAD maka pengalokasian belanja daerah dapat juga meningkat. Komponen belanja daerah yang dapat mempengaruhhi pertumbuhan ekonomi salah satunya adalah belanja modal. Belanja modal merupakan belanja yang jumlahnya memerlukan anggaran modal yang besar, diperuntukkan untuk meningkatkan infrakstruktur, prasarana dan sarana publik. Belanja modal bersifat pengeluaran rutin yang digunakan untuk pembentukan modal, pengeluaran dapat berupa pembelian atau pengadaan dan atau pembangunan aset tetap publik, yang dipergunakan untuk pelayanan publik (Jaeni dan Anggana, 2016). Semakin tinggi belanja modal yang dilakukan oleh pemerintah daerah mendorong tingkat pertumbuhan ekonomi daerah yang tinggi pula. Dengan infrastruktur, prasarana dan sarana publik yang memadai, masyarakat akan lebih mudah dalam akses kegiatan ekonomi, sehingga mendorong meningkatkan pendapatan dan kemakmuran masyarakat. Akan tetapi tidak dapat dipungkiri bahwa terkadang pemerintah daerah dalam mengalokasikan belanja modal tidak selalu dapat mendukung pertumbuhan ekonomi. Misalnya pembelian aset untuk para aparat pemerintah, seperti pembelian mobil dinas, hal itu tidak meningkatkan pertumbuhan ekonomi, karena pengeluaran yang dilakukan tidak mendorong peningkatan produksi suatu daerah.

Kajian hasil penelitian terdahulu mengenai kinerja keuangan daerah terhadap pertumbuhan ekonomi, dan belanja modal sebagai variabel moderator telah dilakukan oleh peneliti terdahulu. Adapun hasil penelitian-penelitian sebelumnya mendapatkan ketidakkonsistenan hasil. Hasil penelitian Ani dan Dwirandra (2014), mendapatkan hasil bahwa kinerja keuangan daerah yang diukur dengan rasio kemandirian daerah memiliki pengaruh positif dan signifikan terhadap pertumbuhan ekonomi, sedangkan rasio efisiensi, rasio efektivitas, dan rasio pertumbuhan pendapatan tidak mempunyai pengaruh yang signifikan terahadap pertumbuhan ekonomi. Berbeda dengan hasil penelitian Siregar (2016), hasil penelitian menunjukkan bahwa kinerja keuangan daerah yang diproksikan dengan rasio kemandirian dan efisiensi tidak berpengaruh signifikan terhadap pertumbuhan ekonomi. Hasil penelitian Gunantara (2014); 
Saraswati dan Ramantha (2018) mendapatkan hasil bahwa belanja modal memperlemah pengaruh PAD terhadap pertumbuhan ekonomi. Adapun hasil penelitian Siregar (2016), belanja modal tidak memperkuat pengaruh kinerja keuangan daerah terhadap pertumbuhan ekonomi.

Pada penelitian ini, peneliti mengangkat topik yang sama untuk menguji kembali kinerja keuangan daerah terhadap pertumbuhan ekonomi, serta menguji bagaimana belanja modal memoderasi kinerja keuangan daerah terhadap pertumbuhan ekonomi. Tujuan penelitian ini untuk menguji dan menganalisis pengaruh kinerja keuangan daerah yang diproksikan denga rasio kemandirian, rasio desentralisasi, dan rasio efisiensi keuangan daerah terhadap pertumbuhan ekonomi, serta menganalisis kemampuan belanja modal dalam memoderasi pengaruh kinerja keuangan daerah terhadap pertumbuhan ekonomi pada kota dan kabupaten di wilayah karesidenan Kediri, Jawa Timur.

\section{KAJIAN PUSTAKA}

\section{Pertumbuhan ekonomi}

Pertumbuhan ekonomi merupakan proses kenaikan produk nasional bruto riil atau pendapatan nasional riil, atau dapat dikatakan adanya kenaikan output perkapita. Pertumbuhan ekonomi dapat dijadikan indikator keberhasilan dalam pembangunan. Pertumbuhan ekonomi yang meningkat terus menerus dapat menjadi tolak ukur tingkat kesejahteraan masyarakat yang juga meningkat. Pertumbuhan ekonomi dapat dipengaruhi oleh beberapa faktor, diantaranya investasi dalam modal aset tetap, pertumbuhan penduduk, dan kemajuan teknologi (Apriana dan Suryanto, 2010). Aset tetap yang berwujud sarana dan infrastruktur, mengakibatkan aktivitas ekonomi menjadi lancar, distribusi barang dan jasa menjadi lebih mudah dan cepat, sehingga meningkatkan pendapatan masyarakat. Kemajuan teknologi dapat mempercepat dan mendukung produktivitas masyarakat, misalnya dengan mesindan peralatan yang lebih canggih dan modern, maka barang dan jasa yang diproduksi juga meningkat, dan meningkatkan pendapatan.

\section{Kinerja Keuangan Daerah}

Kinerja keuangan daerah merupakan capaian kerja pada bidang keuangan yang telah dilaksanakan oleh pemerintah daerah, yang terdiri atas anggaran beserta realisasinya dalam periode anggaran. Alat untuk analisis kinerja keuangan daerah 
dapat menggunakan analisis rasio terhadap APBD yang ditetapkan dan dilaksanakan. Analisis rasio yang dipergunakan dalam menganalisis kinerja keuangan daerah meliputi: rasio kemandirian, rasio efektivitas dan efisiensi, rasio desentralisasi, rasio aktivitas dan rasio lainya. Pengelolaan keuangan daerah yang efektif, ekonomis, dan efisien dapat mendorong pertumbuhan ekonomi. Kemajuan daerah dapat diukur dari meningkatnya kegiatan perekonomian dan mengalami pertumbuhan ekonomi yang tinggi.

Adapun rasio untuk menganalisis keuangan daerah yang digunakan dalam penelitian ini adalah:

\section{Rasio Kemandirian}

Rasio yang mengukur tingkat kemampuan daerah dalam membiayai sendiri kegiatan pemerintahannya, dengan cara mengukur rasio pendapatan asli daerah terhadap bantuan pemerintah pusat dan pinjaman (Bisma dan Susanto, 2010)

Rasio kemandirian

$=\frac{\mathrm{PAD}}{\text { Bantuan Pemerintah Pusat atau Propinsi }+ \text { pinjaman }} x 100 \%$

\section{Rasio Desentralisasi}

Rasio yang menunjukkan tingkat kewenangan dan tanggung jawab dari pemerintah pusat kepada pemerintah daerah untuk melaksanakan kegiatan pembangunan (Bisma dan Susanto, 2010)

$$
\text { RasioDesentralisasi }=\frac{\text { PAD }}{\text { Total Pendapatan Daerah }} \times 100 \%
$$

\section{Rasio Efisiensi}

Rasio untuk mengukur apakah kegiatan pemerintah sudah dilaksanakan secara efisien atau belum, dengan cara menghitung rasio antara output dengan input. Semakin besar output dibandingkan dengan input, maka semakin tinggi tingkat efisiensinya

( Mardiasmo, 2004)

Rasio Efisiensi $=\frac{\text { Biaya pemerolehan PAD }}{\text { Realisasi penerimaan PAD }} \times 100 \%$

\section{Belanja Modal}

Belanja modal merupakan pengeluaran pemerintah yang bersifat rutin dan memerlukan anggaran yang besar. Belanja modal dipergunakan untuk pembelian atau pengadaan dan atau pembangunan aset tetap yang mempunyai nilai ekonomis lebih 
dari satu tahun dan digunakan untuk pelayanan publik (Jaeni dan Anggana, 2016). Aset tetap sebagai wujud belanja modal seperti jalan, bangunan, jembatan, pasar, jaringan dan irigasi, gedung atau dapat berwujud prasarana dan sarana serta infrastruktur. Pengalokasian belanja modal yang tepat yang bersinggungan langsung dengan publik untuk dimanfaatkan masyarakat, dapat meningkatkan dan memperlancar kegiatan ekonomi masyarakat. Dengan lancarnya kegiatan ekonomi masyarakat seperti produktivitas yang tinggi, maka mendorong meningkatnya pendapatan dan pertumbuhan ekonomi. Adapun pemerintah daerah dapat saja mengalokasikan belanja modal yang tidak mempengaruhi pertumbuhan ekonomi. Hal ini dapat terjadi jika belanja yang dilakukan tidak meningkatkan produksi suatu daerah, meskipun konsumsi naik. Misalnya pembelian mobil dinas, pembangunan gedung pemerintah.

Berdasarkan uraian tersebut di atas, hipotesis yang diajukan dalam penelitian ini sebagai berikut:

$\mathrm{H}_{1}$ : Kinerja keuangan daerah berpengaruh signifikan terhadap pertumbuhan ekonomi.

$\mathrm{H}_{2}$ : Belanja modal berpengaruh signifikan terhadap pertumbuhan ekonomi.

$\mathrm{H}_{3}$ : Belanja modal sebagai moderator kinerja keuangan terhadap pertumbuhan ekonomi.

\section{METODE PENELITIAN}

Penelitian ini termasuk dalam penelitian statistik deskriptif. Penelitian dilakukan pada 2 kota dan 5 kabupaten dalam Wilayah Karisedenan Kediri, Provinsi Jawa Timur, yaitu Kota Kediri, Kota Blitar, Kabupaten Kediri, Kabupaten Nganjuk, Kabupaten Tulungagung, Kabupaten Trenggalek, dan Kabupaten Blitar. Obyek penelitian adalah kinerja keuangan daerah, pertumbuhan ekonomi daerah dan belanja modal daerah dari tahun 2009 sampai dengan tahun 2016. Sumber data yang digunakan dalam penelitian ini adalah data sekunder, yang didapatkan dari Badan Pusat Statistik (BPS) Jawa Timur, Situs Dirjen Perimbangan Keuangan pemerintah Daerah (DPJK), yang terdiri dari data pertumbuhan ekonomi, laporan APBD baik target maupun realisasi. Pengumpulan data menggunakan dokumentasi, yaitu dengan mengunduh data-data yang diperlukan dalam penelitian pada website BPS yaitu 
www.bpsjatim.go.id dan website DPJK yaitu pada www.dpjk.depkeu.go.id. Desain penelitian ini disajikan dalam gambar 1 berikut ini:

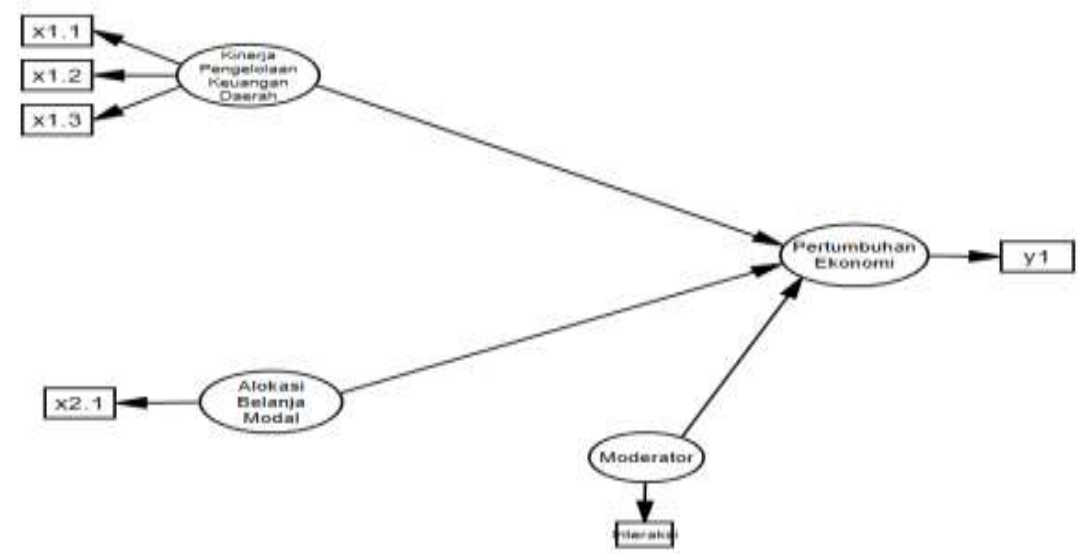

\section{Gambar 1. Desain penelitian}

Dalam penelitian ini, terdapat 3 variabel, yaitu variabel bebas, variabel terikat dan varaibel moderator. Variabel bebas dalam penelitian ini adalah kinerja keuangan daerah. Kinerja keuangan daerah diproksikan dengan rasio kemandirian daerah, rasio desentralisasi daerah dan efisiensi keuangan daerah. Rasio kemandirian daerah dihitung dengan membandingkan total PAD dengan jumlah penerimaan pendapatan dari transfer (pusat dan propinsi) dan jumlah pinjaman daerah, kemudian dikalikan dengan 100 persen. Rasio desentralisasi daerah dihitung dengan membandingkan total PAD dengan total pendapatan daerah, kemudian dikalikan 100 persen. Adapun rasio efisiensi dihitung dengan total biaya yang dikeluarkan dengan total pendapatan, dan dikalikan 100 persen.

Variabel terikat dalam penelitian ini adalah pertumbuhan ekonomi. Pertumbuhan ekonomi dihitung dengan perbandingan selisih PDRB tahun sekarang dengan PDRB tahun sebelumnya dibandingkan dengan PDRB tahun sebelumnya, dan kemudian dikalikan dengan 100 persen. Belanja modal sebagai variabel moderator, yakni belanja modal dapat meningkatkan atau menurunkan pengaruh kinerja keuangan terhadap pertumbuhan ekonomi. Belanja modal dalam penelitian ini menggunakan alokasi belanja modal yang dihitung dengan membandingkan antara jumlah belanja modal dengan total belanja daerah. Data alokasi belanja modal didapatkan dari data realisasi belanja modal dengan realisasi total belanja daerah. 
Teknik analisis data dalam penelitian ini menggunakan analisis SEM Moderating, dengan menggunakan software AMOS 21. Tahapan dalam analisis SEM Moderating, yaitu pada tahap pertama menganalisis pengaruh kinerja keuangan daerah, belanja modal terhadap pertumbuhan ekonomi. Pada tahap kedua melakukan uji MSEM, dengan belanja modal sebagai moderator kinerja keuangan daerah terhadap pertumbuhan ekonomi. Kriteria pengujian hipotesis dalam penelitian ini, yaitu Ha diterima dan Ho ditolak jika nilai $\mathrm{p}$-value $<0,05$.

\section{HASIL DAN PEMBAHASAN}

Penelitian ini menganalisis pengaruh kinerja keuangan daerah yang diproksikan dengan rasio kemandirian daerah, rasio desentralisasi daerah dan rasio efisiensi daerah, terhadap pertumbuhan ekonomi dengan belanja modal sebagai variabel moderator. Tahap pertama dalam analisis MSEM adalah melakukan analisis pengaruh kinerja keuangan daerah dan belanja modal terhadap pertumbuhan ekonomi, untuk menghasilkan estimasi $\lambda$ dan $\Theta$ pada variabel kinerja keuangan daerah dan belanja modal. Hasil dari SEM menggunakan Amos 21 estimasi $\lambda$ dan $\Theta$, disajikan dalam tabel 1 berikut ini:

Tabel 1.Error Variance dan Loading Factor

\begin{tabular}{|c|c|c|c|c|c|}
\hline \multirow[b]{2}{*}{ Indikator } & \multicolumn{2}{|c|}{ Kinerja } & \multirow[b]{2}{*}{ Indikator } & \multicolumn{2}{|c|}{$\begin{array}{c}\text { Alokasi Belanja } \\
\text { Modal }\end{array}$} \\
\hline & $\begin{array}{l}\theta \text { (error } \\
\text { variance) }\end{array}$ & $\begin{array}{c}\lambda \\
\text { (loading } \\
\text { factor) }\end{array}$ & & $\begin{array}{c}\theta \text { (error } \\
\text { variance) }\end{array}$ & $\begin{array}{c}\lambda \\
\text { (loading } \\
\text { factor) }\end{array}$ \\
\hline$x 1.1$ & 1,000 & 0,976 & $x 2.1$ & 1,000 & 0,981 \\
\hline$x 1.2$ & 1,000 & 0,961 & & 1,000 & 0,981 \\
\hline \multirow[t]{2}{*}{$x 1.3$} & 30,71 & 0,006 & & & \\
\hline & 32,71 & 1,943 & & & \\
\hline
\end{tabular}

Langkah selanjutnya adalah mendapatkan $\lambda$ interaksi yang merupakan loading factor dari variabel laten interaksi dan $\Theta$ interaksi yang merupakan error variance dari indikator variabel laten interaksi. Formula yang digunakan sebagai berikut: 


$$
\begin{aligned}
\lambda_{\text {moderating }}= & \left(\lambda x_{1.1}+\lambda x_{1.2}+\lambda x_{1.3}\right)\left(\lambda x_{2.1}\right) \\
= & (1,943)(0,981) \\
= & 1,906 \\
\theta= & \left(\lambda x_{1.1}+\lambda x_{1.2}+\lambda x_{1.3}\right)^{2} V A R(\text { kinerja })\left(\theta_{\text {alokasi }}\right) \\
& +\left(\lambda x_{2.1}\right)^{2} V A R(\text { alokasi })\left(\theta x_{1.1}+\theta x_{1.2}+\theta x_{1.3}\right) \\
& +\left(\theta x_{1.1}+\theta x_{1.2}+\theta x_{1.3}\right)\left(\theta x_{2.1}\right) \\
= & (1,943)^{2}(0,001)(1,000)+(0,981)^{2}(25,043)(32,716)+(32,716)(1,000) \\
= & 821,189
\end{aligned}
$$

Nilai $\lambda$ imoderating dari analisis pertama didapatkan hasil 1,906 dan $\Theta$ moderating sebesar 821,189 dimasukkan dalam tahap kedua. Hasil akhir MSEM adalah sebagai berikut:

Tabel 2 Standardized Regression Weight Structural Model

\begin{tabular}{|l|l|l|l|l|l|l|}
\hline \multicolumn{2}{|l|}{ Kausalitas } & $\begin{array}{l}\text { Standardized } \\
\text { Estimate }\end{array}$ & S.E. & C.R. & P \\
\hline Pertumbuhan & $<--$ & Kinerja & $-0,100$ & 0,015 & - & 0,266 \\
& & & & 1,113 & \\
\hline Pertumbuhan & $<--$ & Alokasi & $-0,216$ & 0,017 & - & 0.017 \\
\hline Pertumbuhan & $<---$ & Moderator & $-0,207$ & 0,000 & - & 0,018 \\
& & & & 2,383 & \\
\hline
\end{tabular}

Berdasarkan pada tabel 2 di atas, pengujian hipotesis sebagai berikut:

\section{Hipotesis pertama}

Kinerja keuangan daerah berpengaruh signifikan terhadap pertumbuhan ekonomi.

$H_{0}: \beta_{1}=0$ kinerja keuangan daerah tidak berpengaruh signifikan terhadap pertumbuhan ekonomi

$H_{1}: \beta_{1} \neq 0$ kinerja keuangan daerah berpengaruh signifikan terhadap pertumbuhan ekonomi

Hasil pengujian hipotesis pertama menunjukkan nilai $\beta_{1}=-0,100 \mathrm{dengan}$ nilai $\mathrm{p}-$ value sebesar 0,266 , yang berarti terima $\mathrm{H}_{0}$. Hal ini menunjukkan bahwa kinerja 
keuangan daerah tidak berpengaruh signifikan terhadap pertumbuhan ekonomi. Nilai koefisien path yang negatif menunjukkan bahwa semakin baik kinerja keuangan daerah tidak meningkatkan pertumbuhan ekonomi, atau pertumbuhan ekonomi menurun.

\section{Hipotesis kedua}

Belanja modal berpengaruh signifikan terhadap pertumbuhan ekonomi.

$H_{0}: \beta_{2}=0$, belanja modal tidak berpengaruh signifikan terhadap pertumbuhan ekonomi

$H_{1}: \beta_{2} \neq 0$, belanja modal berpengaruh signifikan terhadap pertumbuhan ekonomi

Hasil pengujian hipotesis kedua menunjukkan nilai $\beta_{2}=-0,216$ dengan nilai $\mathrm{p}-$ value sebesar 0,017, yang berarti tolak $\mathrm{H}_{0}$. Hal ini menunjukkan bahwa kinerja keuangan daerah berpengaruh signifikan terhadap pertumbuhan ekonomi. Nilai koefisien path yang negatif menunjukkan bahwa semakin meningkat belanja modal tidak meningkatkan pertumbuhan ekonomi, atau pertumbuhan ekonomi menurun.

\section{Hipotesis ketiga}

Belanja modal sebagai moderator kinerja keuangan daerah terhadap pertumbuhan ekonomi.

$$
\begin{array}{ll}
H_{0}: \beta_{3}=0 \quad \text { belanja modal sebagai variabel moderator tidak berpengaruh signfikan } \\
\\
\text { terhadap pertumbuhan ekonomi } \\
H_{1}: \beta_{3} \neq 0 \quad \text { belanja modal sebagai variabel moderator berpengaruh signifikan } \\
\\
\text { terhadap pertumbuhan ekonomi }
\end{array}
$$

Hasil pengujian hipotesis ketiga menunjukkan nilai $\beta_{3}=-0,2017$ dengan nilai $p-$ value sebesar 0,018, yang berarti tolak $\mathrm{H}_{0}$. Hasil ini menunjukkan bahwa belanja modal sebagai variabel moderator berpengaruh signifikan terhadap pertumbuhan ekonomi. Hal ini berarti belanja modal dapat sebagai moderator kinerja keuangan daerah terhadap pertumbuhan ekonomi.

Hasil penelitian menunjukkan bahwa hipotesis pertama ditolak. Kinerja keuangan daerah tidak berpengaruh signifikan terhadap pertumbuhan ekonomi dan bernilai negatif. Tinggi rendahnya penerimaan daerah baik yang berasal dari PAD, dana perimbangan ataupun yang lain tidak mempengaruhi pertumbuhan ekonomi. 
Hasil ini menunjukkan bahwa tingkat kemandirian daerah tidak dapat dipergunakan sebagai tolak ukur dalam peningkatan pertumbuhan ekonomi. Hal ini dimungkinkan bahwa meningkatnya PAD tidak didapatkan dari meningkatnya jumlah produktivitas masyarakat, artinya meningkatnya pendapatan daerah tidak berasal dari aktivitas perekonomian dari masyarakat di daerah tersebut, bisa saja pendapatan daerah mayoritas berasal dari transfer pendapatan dari pemerintah provinsi dan pemerintah pusat. Hasil temuan ini mengindikasikan belum maksimalnya pemerintah menggali potensi kekuatan lokal yang dimiliki, seperti mempermudah proses investasi, pengelolaan hasil kekayaan daerah. Hasil penelitian ini mendukung penelitian Siregar (2016) yang menyatakan bahwa kinerja keuangan daerah yang diproksikan dengan rasio kemandirian dan efisiensi tidak berpengaruh signifikan terhadap pertumbuhan ekonomi. Serta penelitian Apriana dan Suryanto (2016), yang menemukan hasil bahwa rasio kemandirian daerah tidak berpengaruh terhadap pertumbuhan ekonomi.

Hipotesis kedua dalam penelitian ini diterima. Belanja modal berpengaruh terhadap pertumbuhan ekonomi, akan tetapi bernilai negatif. Peningkatan belanja modal mempunyai pengaruh terhadap pertumbuhan ekonomi, dikarenakan dengan infrastruktur, prasarana dan sarana yang memadai akan mendorong meningkatnya kegiatan ekonomi masyarakat. Belanja modal merupakan komponen belanja yang menghasilkan output aset tetap. Aset tetap tersebut pemanfaatannya ada yang secara langsung untuk pelayanan publik seperti jalan, jembatan, pasar dan lainnya. Adapun ada yang secara tidak langsung aset tetap tersebut dimanfaatkan oleh publik, misalnya gedung kantor pemerintahan. Dalam kebijakan publik, belanja modal lebih diprioritaskan untuk pelayanan publik, akan tetapi tidak selalu berhubungan langsung dengan pelayanan publik. Hasil penelitian yang menunjukkan hubungan negatif antara belanja modal dengan pertumbuhan ekonomi, dapat dimungkinkan bahwa belanja modal yang dilakukan pemerintah, tidak secara langsung berhubungan dengan pelayanan publik, yang dapat mendorong meningkatnya kegiatan perekonomian masyarakat. Belanja modal yang dialokasikan tinggi, dipergunakan untuk membangun gedung kantor pemerintahan, sehingga secara tidak langsung tidak mempengaruhi kegiatan perekonomian masyarakat, sehingga meningkatnya belanja modal tidak mendorong meningkatnya pertumbuhan ekonomi. Hasil penelitian ini mendukung penelitian Arini (2016), yang menunjukkan hasil bahwa belanja modal berpengaruh signifikan negatif terhadap pertumbuhan ekonomi. 
Hipotesis ketiga dalam penelitian ini diterima. Belanja modal dapat sebagai moderator kinerja keuangan daerah terhadap pertumbuhan ekonomi. Pemerintah dalam melakukan perencanaan pendapatan dan bealanjanya dipergunakan untuk meningkatkan kegiatan perekonomian. Dengan perencanaan yang baik terkait estimasi pendapatan dan pengalokasian belanja, diharapkan pertumbuhan ekonomi daerah akan meningkat. Adapun hasil penelitian ini menunjukkan bahwa belanja modal memperlemah hubungan kinerja keuangan daerah terhadap pertumbuhan ekonomi. Hal ini dapat dikarenakan pemerintah dalam upaya meningkatkan pendapatan dan alokasi belanjanya khususnya belanja modal tidak berinteraksi secara langsung kegiatan perekonomian, sehingga walaupun pendapatan dan belanja modal meningkat tetapi tidak mendukung kegiatan ekonomi yang mengakibatkan tidak meningkatkan pertumbuhan ekonomi. Hasil penelitian ini mendukung penelitian Gunantara (2014); Siregar (2016); Saraswati dan Ramantha (2018), yang mendapatkan hasil bahwa belanja modal memperlemah pengaruh kinerja keuangan daerah terhadap pertumbuhan ekonomi.

\section{SIMPULAN DAN SARAN}

Hasil penelitian ini menemukan bahwa kinerja keuangan daerah yang diukur dengan rasio kemandirian, rasio desentralisasi, dan rasio efisiensi tidak berpengaruh pada pertumbuhan ekonomi. Belanja modal berpengaruh signifikan terhadap pertumbuhan ekonomi dan dapat sebagai variabel moderator kinerja keuangan daerah terhadap pertumbuhan ekonomi. Belanja modal dalam penelitian ini memperlemah pengaruh kinerja keuangan daerah terhadap petumbuhan ekonomi.

Pemerintah daerah di Wilayah Karesidenan Kediri hendaknya memperhatikan estimasi pendapatan dan alokasi belanja modal untuk meningkatkan kegiatan perekonomian. Hal ini dapat diwujudkan dengan mengalokasikan belanja modal yang bersinggungan secara langsung dengan aktivitas ekonomi, misalnya alokasi untuk perbaikan jalan, jembatan, pembangunan pasar.

Penelitian selanjutnya dapat memperluas daerah penelitian, misalnya lingkup satu provinsi, dengan variabel penelitian yang lebih banyak, misalnya faktor kemajuan teknologi, alokasi DAU yang mempengaruhi pertumbuhan ekonomi. 


\section{DAFTAR PUSTAKA}

Apriana, D, dan R. Suryanto. 2010. Analisis hubungan antara Belanja Modal, Pendapatan Asli Daerah, Kemandirian Daerah dan Pertumbuhan Ekonomi Daerah (Studi pada kabupaten dan Kota se Jawa-Bali). Jurnal Akuntansi $\mathcal{E}$ Investasi, 11(1): 68-79.

Ani, NLNP dan AANB Dwirandra. 2014. Pengaruh Kinerja Keuangan Daerah Pada Pertumbuhan Ekonomi, Pengangguran, dan Kemiskinan Kabupaten dan Kota. E-Jurnal Akuntansi Universitas Udayana, 6(3): 481-497. ISSN: 2302-8556.

Arini, P.R. 2016. Pengaruh Belanja Modal Terhadap Pertumbuhan Ekonomi dan Kesejahteraan Masyarakat di Pulau Kalimantan. JRAMB, 2(2):180-198.

Bisma, I. D. G dan H. Susanto. 2010. Evaluasi Kinerja Keuangan Daerah Pemerintah Propinsi Nusa Tenggara Barat Tahun Anggaran 2003-3007.Jurnal Ganec Swara Edisi Khusus, 4(3).

Gunantara, P.C. 2014. Pengaruh Pendapatan Asli Daerah dan Dana Alokasi Umum terhadap Pertumbuhan Ekonomi dengan Belanja Modal sebagai Variabel Pemoderasi di Provinsi Bali. E-Jurnal akuntansi, 7(3).

Jaeni dan G. Anggana. 2016. Pertumbuhan Ekonomi sebagai Variabel Pemoderasi Pendapatan Asli Daerah dan Bantuan Propinsi Terhadap Belanja Modal. Dinamika Akuntansi, Keuangan dan Perbankan, 5(1): 13-26. ISSN: 1979-4878.

Mardiasmo. 2004.Otonomi dan Manajemen Keuangan Daerah. Yogyakarta: ANDI.

Saraswati, I.A., dan I. W. Ramantha. 2018. Pengaruh Pendapatan Asli Daerah terhadap Pertumbuhan Ekonomi dengan Belanja Modal dan Investasi Swasta sebagai Pemoderasi. E-Jurnal Akuntansi Universitas Udayana, 24(1): 662-686. ISSN: 23028556.

Siregar, H.A. 2016. Analisis Pengaruh Kinerja Keuangan terhadap Pertumbuhan Ekonomi Provinsi Riau dengan Belanja Modal sebagai Variabel Pemoderasi. Kurs, 1(1): 140-152.

Peraturan Menteri Dalam Negeri Nomor 13 Tahun 2006 Tentang Pedoman Pengelolaan Keuangan Daerah. 